\title{
Peran Arbitrase di Bank Syariah dalam Penyelesaian Sengketa
}

\author{
Ulfa Hasanah \\ IAIN Madura \\ ulfahasanah0096@gmail.com
}

\begin{abstract}
The Indonesian muamalah arbitration board was officially established on October 211993. Based on the decision letter of the Indonesian Ulama Council no. Kep/09/MUI/XXI/2003 dated December 24, 2003, in the name BAMUI was changed to the National Sharia arbitration body (BASYARNAS). The application of arbitration as a dispute resolution in Islamic banks through the national Sharia arbitration board is a research called normative juridical. Every sharia bank activity must comply with the fatwa of the National Sharia Council of the Indonesian Ulema Council, as well as the resolution of disputes in sharia banks. The National Sharia Arbitration Board has procedural regulations in accordance with the provisions of law number 30 of 1999 concerning arbitration and alternative dispute resolution.
\end{abstract}

Key words: arbitration, sharia arbitration, BASYARNAS, DSN MUI

\begin{abstract}
Abstrak
Badan arbitrase muamalah Indonesia berdiri secara resmi pada tanggal 21 Oktober 1993. Berdasarkan surat keputusan Majelis Ulama Indonesia nomor Kep/09/MUI/XXI/2003 tanggal 24 Desember 2003, nama BAMUI diubah menjadi badan arbitrase Syariah Nasional (BASYARNAS). Penerapan arbitrase sebagai penyelesaian sengketa di bank syariah melalui badan arbitrase Syariah nasional merupakan penelitian yang disebut dengan yuridis normatif. Setiap kegiatan bank syariah harus sesuai dengan fatwa Dewan Syariah Nasional Majelis Ulama Indonesia, demikian pula dengan penyelesaian sengketa pada bank syariah. Badan Arbitrase Syariah Nasional memiliki peraturan prosedur yang sesuai dengan ketentuan undang-undang nomor 30 tahun 1999 tentang arbitrase dan alternatif penyelesaian sengketa.
\end{abstract}

Kata kunci: Arbitrase, Arbitrasi Syariah, BASYARNAS, DSN MUI

\section{PENDAHULUAN}

Keberadaan dan perkembangan arbitrase sebagai forum penyelesaian sengketa menunjukkan realitas ketertinggalan apabila dibandingkan de-ngan perkembangan arbitrase di luar negeri misalnya di Paris dengan Tribunal Court of International Chamber of Commerce atau ICC yang didirikan tahun 1899. Padahal tata hukum Indonesia sebenarnya telah mengenal insti- tusi arbitrase sebagai ADR dengan dikodifikasikannya peraturan mengenai institusi tersebut dalam RV dengan St. 1847 No. 52 jo. St. 1849 No. 60 khusus- nya buku III Bab I (pasal 615-651 RV). Semula ketentuan tersebut hanya ber- laku bagi golongan Eropa dan Tionghoa berdasarkan Pasal 131 IS (Indische Staatsregelaring). Namun dengan 
adanya pasal 377 HIR . St. 1941-44 dan pasal 705 RBG. St. 1927-227, ketentuan pasal 615-651 RV ini diperluas sehingga golongan Pribumi dan Timur Asing juga dapat menyelesaikan sengketa melalui arbitrase (Dewi, 2019:47).

Menurut Subekti, arbitrase adalah penyelesaian suatu perselisihan (perkara) oleh seorang atau beberapa orang wasit (debitur) yang bersamasama ditunjuk oleh para pihak yang berperkara dengan tidak diselesaikan lewat pengadilan.' Pasal 615 ayat (1) Rv menyebutkan bahwa setiap orang dapat menyerahkan perselisihan mengenai hak-hak yang ia kuasai secara bebas kepada keputusan wasit. Selanjutnya UU No. 30 Tahun 1999 tentang Arbitrase dan Alternatif Penyelesaian Sengketa memberikan definisi arbitrase sebagai cara penyelesaian sengketa perdata di luar peradilan umum yang didasarkan pada perjanjian arbitrase yang dibuat secara tertulis oleh para pihak yang bersengketa (Dewi, 2019:48).

Dalam hal sengketa bidang Perbankan Syariah, Proses penyelesaian sengketa perbankan syariah bisa diselesaikan melalui forum litigasi yaitu pengadilan agama dan forum non ligitasi yaitu Badan Arbitrase Syariah Nasional. , dalam perjanjian tertulis antara para pihak berlaku asas kebebasan berkontrak dalam memilih forum yang dianggap lebih efektif. Prinsip penyelesaian sengketa melalui arbitrase Syariah dalam kegiatan usaha ataupun penyelesaian sengketa merupakan unsur kepatuhan Syariah (Syariah complianse) terdapat dalam anutan undang-undang nomer 21 tahun 2018 tentang perbankan syariah. Segala hasil penyelesaian sengketa baik melalui arbitrase ataupun alternatif penyelesaian sengketa harus sesuai atau tidak boleh bertolak belakang dengan prinsip syariah, sehingga prinsip syariah harus benar-benar diterapkan dalam kasus penyelesaian sengketa. Ruang lingkup sengketa perbankan syariah yang dapat diselesaikan melalui arbitrase Syariah bergantung pada kesadaran hukum dari pihak pihak bersengketa yaitu antara nasabah dan tim Bank Syariah. Arbitrase dalam hukum Islam disebut dengan istilah tahkim. Tahkim adalah pengangkatan seorang wasit atau juru damai oleh orang yang bersengketa guna menyelesaikan perkara yang mereka perselisihkan secara damai.

Perbankan syariah adalah suatu sistem perbankan yang dikembangkan berdasarkan prinsip syariah hukum Islam. Pengertian perbankan syariah menurut pasal 1 butir 1 undang-undang nomor 21 tahun 2001 tentang perbankan syariah sebagai berikut. Perbankan syariah adalah suatu sistem segala sesuatu yang menyangkut tentang Bank Syariah mencakup kelembagaan kegiatan usaha serta cara dan proses dalam melaksanakan kegiatan usahanya (Ariesta, 2014:8).

Bank Syariah merupakan suatu lembaga keuangan yang menerapkan system perbankan yang telah sesuai dengan prosedur yang 
sesuai Al-Qur'an dan Al-Hadits dan telah distujui oleh DSN (Dewan Syariah Nasional).

Sengketa yang terjadi harus diselesaikan agar tidak ada para pihak yang merasa dirugikan. Tujuan diadakannya penyelesaian sengketa ini agar setiap permasalahan-permasalahan yang ada dalam perbankan dapat terselesaikan dengan sebagaimana mestinya. Sehingga tidak menimbulkan persengketaan yang berujung pada ketidakadilan. Dalam tradisi Islam klasik, terdapat tiga bentuk mekanisme penyelesaian sengketa yang pernah berkembang, baik pada masa Rasulullah Saw, Para Sahabat, Khalifah Bani Umayyah, dan Bani Abbasiah, yaitu: sulh/perdamaian, tahkim/arbitrase, dan proses litigasi yang disebut dengan wilayat al-aqda/kekuasaan kehakiman (Ariesta, 2014:10).

Dalam suatu permasalahan sengketa wajib diselesaikan dikarnakan telah terjadi suatu kerugian yang dialami oleh salah satu dalam hal sengketa tersebut. Dengan adanya penyelasaian kasus tersebut diharapkan telah selesai masalah tersebut dengan menempuh jalur arbitrase.

Menurut penjelasan umum undang-undang arbitrase Syariah, landasan filosofis dibentuk undang-undang arbitrase lembaga arbitrase mempunyai kelebihan, sebagai lembaga penyelesaian sengketa jika dibandingkan dengan lembaga peradilan umum. Kelebihan arbitrase yaitu kerahasiaan sengketa para pihak dijamin, dapat dihindari kelambatan yang diakibatkan karena hal prosedur dan administrasi, para pihak memilih arbiter yang menurut keyakinan mempunyai pengetahuan serta latar belakang yang cukup mengenai masalah yang disengketakan jujur dan adil (Sudiyana, 2017:127).

Arbitase memiliki keunggulan dalam pelayanan penyelesaian kasus sengketa yang salah satunya dijamin atas kerahasiaan sengketa tersebut. Dalam hal Mudharabah juga, Apabila terjadi kasus dalam pembagian laba antara Mudharib dan Shahibul maal Kemudian terjadi sebuah kerugian yg di akibatkan oleh Mudharib, maka Kesalahan tersebut merupakan tanggung jawab atas mudharib. Dalam kasus tersebut, Badan Arbitrase atau pengadilan berperan penting dalam menentukan hasiI putusan.

Semakin lama Menunda untuk memulai proses arbitrase, Berdasarkan pengalaman dalam praktek menimbulkan kombinasi sebab selama proses negoisasi dapat memecahkan masalah-masalah baru yang mengakibatkan sengketa yang dihadapi para pihak semakin kompleks. Dengan demikian, persoalan Kapan para pihak akan memulai proses arbitrase merupakan suatu yang strategik (Abdul Wahid, 2005:61).

Sehingga dalam hal ini, pihak yang bersengketa diharapkan menyelesaikan permasalahannya melaui jalur arbitrase yang bertujuan untuk menghindari terjadi masalah yang semakin sulit untuk diselesaikan.

Penyelesaian sengketa dengan "tahkim" yang kata kerjanya adalah "hakkama" secara harfiah berarti menjadikan seseorang sebagai penengah 
bagi suatu sengketa. Lembaga tahkim telah dikenal sejak zaman pra Islam. Pada masa itu, meskipun belum terdapat sistem peradilan yang terorganisir, setiap ada perselisihan mengenai hak milik Waris dan hak lainnya seringkali diselesaikan melalui bantuan juru Damai atau wasit yang ditunjuk oleh masing-masing pihak yang berselisih (Zaidah, 2016:123).

Sebelum terbentuknya badan Arbitrase, dalam penyelesaian kasus saat zaman pra Islam adalah Lembaga Tahkim yang bertugas sebagai penengah dalam suatu permasalahan Sengketa. Arbitrase merupakan salah satu mekanisme alternatif penyelesaian sengketa yang cukup sering digunakan umumnya dalam sengketa bisnis. Arbitrase dipandang sebagai suatu mekanisme efektif yang dapat mengakomodasi kepentingan para pihak yang terlibat di dalamnya karena tata cara pelaksanaannya dapat ditentukan dengan kesepakatan dan sifatnya yang bersifat rahasia (Novita, 2006). Alternatif penyelesaian sengketa telah banyak digunakan pada era modernisasi ini, terutama dalam bidang perdagangan. Hal ini dikarenakan kompleksnya permasalahan dalam bidang ekonomi dan semakin heterogennya pihak yang terlibat dalam lapangan usaha tersebut salah satunya dalam bentuk lembaga alternatif penyelesaian sengketa adalah lembaga arbitrase (Farah, 2020).

Arbitrase merupakan suatu pilihan cara yang dapat dipilih dan ditunjuk secara sukarela oleh para pihak Berdasarkan kesepakatan untuk menyelesaikan sengketa. Kesepakatan tersebut dapat dituangkan dalam perjanjian tertulis yang dibuat di antara para pihak baik sebelum ataupun sesudah terjadinya sengketa, sesuai dengan asas kebebasan berkontrak dalam hukum perdata. Hal tersebut merupakan sebuah upaya dalam penyelesaian sengketa melalui jalur arbiter (Lusianah, 2008).

Arbitrase baik nasional maupun internasional memiliki peran dan fungsi yang makin lama makin penting dalam kerangka proses penyelesaian sengketa. Khususnya bagi Indonesia sebagai negara Niaga kecil yang telah memastikan diri untuk memasuki arena ekonomi dunia yang terintegrasi, arbitrase sangat penting karena tidak ada pengadilan dunia yang dapat menangani sengketa-sengketa komersial yang terjadi dari perdagangan internasional (Multazam, 2006). Penyelesaian sengketa kepada arbitrase dapat dilakukan dengan pembuatan suatu compromise, yaitu penyerahan kepada arbitrase suatu sengketa yang telah lahir atau melalui perbuatan satu Klausa arbitrase dalam suatu perjanjian sebelum sengketanya lahir clause compromisoire (Wagianto, 2020:8). Arbitrase terdiri dari arbitrase nasional dan internasional yang penyelesaian sengketanya dapat dilakuka dengan pembuatan compromise.

Penyelesaian perkara melalui musyawarah dengan artian bertemunya antara pihak yang bersengketa dalam satu majelis, pada dasarnya adalah jalur terbaik. Keuntungan yang didapatkan kedua pihak yang bersengketa setidaknya adalah penemuan solusi atau jalan keluar 
yang sama-sama disepakati. Hal tersebut akan lebih sempurna jika jalur penyelesaian sengketa ini di konteskan dengan fenomena yang terjadi di dunia modern. Banyaknya tuntutan terhadap seseorang, menjadikan keberadaan jalur penyelesaian semacam (arbitrase) seharusnya tumbuh subur (Amrullah, 2013:91). Mengenai penyelesaian sengketa ekonomi syariah melalui badan arbitrase Syariah dengan pedoman pada undangundang nomor 30 tahun 1999 menunjukkan bahwa arbitrase Syariah sebagai salah satu cara penyelesaian sengketa atau perkara antara para pihak bersangkutan di luar peradilan dengan relevansi arbitrase undangundang nomor 30 tahun 1999 dalam memberikan kekuatan dan dasar hukum bagi badan arbitrase dalam melaksanakan eksekusi putusan perkara antara pihak yang bersengketa, sehingga putusan yang dijatuhkan bersifat final dan mengikat kedua pihak tersebut (Sulfiayu, 2020).

Arbitrase bisa menjadi solusi penyelesaian masalah terhadap ketidakpastian sehubungan dengan sistem hukum yang berbeda jenis sebabkan karena para pihak yang bersengketa berasal dari yuridis hukum yang tidak sama, alasan dipilihnya arbitrase juga disebabkan karena beberapa hal seperti adanya kebebasan, kepercayaan dan keamanan keahlian cepat dan hemat biaya bersifat rahasia, bersifat non presiden, kepekaan arbiter, pelaksanaan keputusan dan adanya kecenderungan yang modern. Arbitrase merupakan solusi yang tepat terhadap penyelesaian sengketa yang memberikan kekuatan dan dasarr hokum dalam pelakasanaan putusan perkara.

APS (Alternatif Penyelesaian Sengketa) adalah mekanisme penyelesaian sengketa yang berdampingan dengan penyelesaian sengketa melalui pengadilan. Selanjutnya, APS lazimnya dilakukan di luar yurisdiksi pengadilan. Sama seperti istilah "pengobatan alternatif", bahwa "pengobatan alternatif" sama sekali tidak mengeliminasi "pengobatan dokter". Bahkan terkadang keduanya saling berdampingan. Begitu juga dengan APS dan penyelesaian sengketa melalui pengadilan dapat berjalan saling berdampingan. Oleh karena itu, para hakim tidak perlu khawatir dengan digunakannya mekanisme APS, pengadilan menjadi kurang pekerjaannya. Ada beberapa pendapat mengenai APS atau Alternative Dispute Resolution (Raden, 2014:155).

Sadar atau tidak APS sebenarnya sudah sejak lama dikenal di Indonesia. Lembaga-lembaga hukum adat sebenarnya melakukan APS yang berdampingan dengan forum pengadilan. Memang APS yang telah dikenal ini diartikan secara luas, yaitu bukan untuk menyelesaikan sengketa dagang atau bisnis saja, tetapi termasuk juga sengketa-sengketa lain. Hal ini berbeda dengan Undang Undang Arbitrase yang juga mengatur tentang APS (Pasal 6 Undang-Undang No.30 Tahun 1999) dimana pengertian APS harus diinterprestasikan sebagai penyelesaian sengketa khusus untuk bidang perdata (yang berkaitan dengan arbitrase). 
Lembaga-lembaga APS yang dibentuk di Indonesia antara lain: Badan Arbitrase Nasional Indonesia (BANI), Badan Arbitrase Muamalat Indonesia (BAMUI), Pusat Penyelesaian Perselisihan Bisnis Indonesia (P3BI), Indra (Prakarsa Jakarta). Berikut ini akan dibahas beberapa lembaga APS secara singkat (Raden, 2014:158-159).

Anggaran BANI (Badan Arbitrase Nasional Indonesia) sebagian besar berasal dari biaya yang dibayar oleh para pihak yang bersengketa. Biaya yang harus dibayarkan kepada BANI yaitu biaya registrasi sebesar Rp.250.000, dan iaya administrasi dan biaya pemeriksaan Rp.150.000,- sd Rp.250.000,-. Biaya arbitrase itu sendiri didasarkan pada nilai perkara berkisar dari 10\% untuk perkara yang bernilai kurang dari Rp.50 juta sampai antara $2 \%$ dan $5 \%$ untuk perkara yang bernilai dia atas Rp. 750 juta (Raden, 2014:159).

BANI menangani penyelesaian sengketa, baik melalui arbitrase sebagai kelembagaan maupun arbitrase secara ad-hoc. Dalam bentuk pertama, para pihak yang berpekara memilih BANI dan peraturan mengenai prosedurnya. Sedangkan dalam bentuk yang kedua, para pihak dapat membentuk suatu tribunal, menunjuk seorang arbiter, dan membuat prosedur sendiri atau memilih untuk memakai prosedur BANI. Dari pendaftaran sampai dengan penyelesaian akhir perkara, biasanya dibutuhkan waktu dari 3 bulan sampai dengan 6 bulan. Berdasarkan informasi yang diperoleh, hanya beberapa perkara saja yang dibawa ke BANI, karena BANI hanya mampu menyelesaikan rata-rata 4 perkara setiap tahun atau 1 perkara setiap 3 bulan. Hal ini menunjukkan bahwa beban pengadilan belum berkurang dengan adanya BANI, meskipun secara organisasional BANI terdapat sekitar 30 orang arbiter yang terdaftar dari berbagai latar belakang keahlian dan pengalaman (Raden, 2014:159).

BAMUI dibentuk tanggal 23 Oktober 1993. Yurisdiksi BAMUI meliputi penyelesaian sengketa yang timbul dari perdagangan, industri, keuangan, jasa, dan lain-lain, di manapun para pihak menyerahkan secara tertulis penyelesaian sengketanya ke BAMUI.

Pendirian BAMUI (Badan Arbitrase Muamalat Indonesia) berakar dari ajaran yang lazim dalam masyarakat Islam, yaitu ajaran ishlah yang mendukung penyelesaian sengketa secara damai dengan mengenyampingkan perbedaan yang menimbulkan masalah. Dalam penyelesaian ini, para pihak yang bersengketa diminta untuk secara jujur, memaafkan "kesalahan" satu sama lain dan mempraktikkan tindakan "maaf-memaafkan" itu. Ishlah telah digunakan secara luas dan diantara masyarakat Islam dalam penyelesaian sengketa bisnis. Dewasa ini, konteks Ishlah telah menyatu dengan tahkim, yang kata kerjanya adalah hakkama, yang secara harfiah berarti menjadi seorang penengah dalam suatu sengketa. Mekanisme penyelesaian sengketa melalui BAMUI dapat dilakukan dengan arbitrase institusional atau arbitrase ad-hoc, sama seperti 
arbitrase pada umumnya. Penyelesaian ini biasanya memakan waktu 3-6 bulan. Putusan BAMUI adalah final dan mengikat, dan tidak dipublikasikan kecuali atas keinginan para pihak yang terlibat. BAMUI mempunyai kira-kira 30 orang arbiter dari berbagai latar belakang dan pengalaman. Selama ini, BAMUI hanya menangani satu 1 atau 2 perkara mediasi. Tidak ada sengketa yang memerlukan arbitrase (Raden, 2014:160).

Suatu sengketa ditimbulkan karena terdapat salah satu pihak yang dirugikan dan disampaikan atas ketidak nyamanannya terhadap pihak yang merugikan dan pihak yang dianggap merugikan tersebut merasa tidak memiliki tanggung jawab dalam hal tersebut sehingga terjadilah perselisihan atau persengkataan diantara keduanya dan sengketa tersebut dapat diselesaikan melalui cara formal yang menjadi proses adjudikasi melalui pengadilan dan arbitarse.

Berdasarkan UU Nomor 30 Tahun 1999, arbitrase merupakan cara penyelesaian sengketa perdata di luar pengadilan umum yang didasarkan perjanjian arbitrase secara tertulis oleh pihak yang bersengketa. Perjanjian arbitrase merupakan kesepakatan berupa klausula arbitrase yang tercantum dalam suatu perjanjian tertulis yang dibuat para pihak sebelum atau setelah timbul sengeketa. Suatu perjanjian arbitrase tidak menjadi batal walaupun disebabkan oleh suatu keadaan seperti halnya ; Salah satu pihak meninggal, salah satu pihak bangkrut, pembaharuan utang (novasi), salah satu pihak tidak mampu membayar (insolvensi), pewarisan, berlakunya syarat hapusnya perikatan pokok, bilamana pelaksanaan perjanjian tersebut dialih tugaskan pada pihak ketiga dengan persetujuan pihak yang melakukan perjanjian arbitrase tersebut, berakhir atau batalnya perjanjian pokok (Raden, 2014:193).

Terdapat dua jenis arbitrase yaitu arbitrase ad hoc atau arbitrase volunteer; arbitrase ad hoc arbitrase bersifat insidentil yang dibentuk secara khusus untuk menyelesaikan perselisihan tertentu. Kedudukan dan keberadaan arbitrase ini hanya untuk melayani dan memutuskan kasus perselisihan tertentu, setelah sengketa selesai maka keberadaan dan fungsi arbitrase ini berakhir dengan sendirinya. Yang kedua adalah arbitarse institusional merupakan lembaga permanen yang tetap berdiri untuk selamanya dan tidak bubar meski perselisihan yang ditangani telah selesai (Raden, 2014:193).

Pemberian pendapat oleh lembaga arbitrase menyebabkan kedua belah pihak terikat padanya. Apabila tindakannya ada yang bertentangan dengan pendapat tersebut maka dianggap melanggar perjanjian, sehingga terhadappendapat yang mengikat tersebut tidak dapat diajukan upaya hukum atau perlawanan baik upaya hukum banding atau kasasi (Raden, 2014:193-194).

Sementara itu, pelaksanaan putusan arbitrase nasional dilakukan dalam waktu paling lama 30 hari terhitung sejak tanggal putusan 
ditetapkan. Dengan demikian, lembar asli atau salinan otentik putusan arbitrase diserahkan dan didaftarkan oleh arbiter atau kuasanya kepada panitera pengadilan negeri dan oleh panitera diberikan catatan yang berupa akta pendaftaran (Raden, 2014:194).

Putusan arbitrase bersifat final, dibubuhi pemerintah oleh ketua pengadilan negeri untuk dilaksanakan sesuai ketentuan pelaksanaan putusan dalam perkara perdata yang keputusannya telah memiliki kekuatan hukum tetap dan mengikat para pihak, tidak dapat diajukan banding, kasasi, atau peninjauan kembali. Dalam hal pelaksanaan keputusan arbitrase internasional berdasarkan UU Nomor 30 Tahun 1999, yang berwenang menangani masalah pengakuan dan pelaksanaan putusan arbitrase internasional adalah Pengadilan Negeri Jakarta Pusat (Raden, 2014:194).

Sementara itu berdasarkan Pasal 66 UU Nomor 30 Tahun 1999, suatu putusan arbitrase internasional hanya diakui serta dapat dilaksanakan di wilayah hukum RI, jika telah memenuhi persyaratan sebagai berikut; putusan arbitrase internasional dijatuhkan oleh arbiter atau majelis arbitrase di suatu negara yang dengan Negara Indonesia terikat pada perjanjian, baik secara bilateral maupun multilateral mengenai pengakuan dan pelaksanaan putusan arbitrase internasional, putusan arbitrase internasaional terbatas pada putusan yang menurut ketentuan hukum Indonesia termasuk dalam ruang lingkup hukum perdagangan, putusan arbitrase internasional hanya dapat dilakukan di Indonesia dan keputusannya tidak bertentangan dengan ketertiban umum, putusan arbitrase internasonal dapat dilaksanakan di Indonesia setelah memperoleh eksekutor dari ketua Pengadilan Negeri Jakarta Pusat (Raden, 2014:194).

Kecenderungan yang terjadi para pihak lebih memilih penyelesaian sengketa melalui jalur non litigasi karena penyelesaian sengketa melalui jalur litigasi dianggap kurang sesuai dengan dunia bisnis. Penyelesaian sengketa melalui forum arbitrase merupakan suatu lembaga banyak dipilih para pihak karena dianggap lebih sesuai dengan iklim bisnis yang menginginkan semua serba cepat dan efisien (Dewi, 2019:16).

Kesepakatan untuk menggunakan lembaga arbitrase sebagai forum penyelesaian sengketa harus dituangkan dalam perjanjian tertulis. Perjanjian dapat berupa klausul arbitrase yang dicantumkan dalam perjanjian pokok para pihak atau dapat berupa perjanjian arbitrase yang dibuat secara terpisah dari perjanjian pokoknya. Perjanjian tertulis tersebut akan memberikan kewenangan pada majelis arbitrase untuk menyelesaikan ketidaksepahaman yang terjadi diantara para pihak (Dewi, 2019:16-17).

Kekuatan modal, kemampuan teknis dan manajerial pemilik modal asing yang kebanyakan berasal dari negara maju menyebabkan bargaining position mereka lebih kuat daripada pemerintah Indonesia. Kekuatan 
modal asing dalam aktivitasnya menjadi perusahaan multinasional dinilai dapat mempengaruhi bahkan memanipulasi kebijakan politis ke arah yang lebih menguntungkan mereka. Pengaruh tersebut nampak salah satunya dalam pilihan forum penyelesaian sengketa antara modal asing dan pihak nasional untuk diselesaikan hanya melalui arbitrase internasional. Padahal Indonesia sendiri telah memiliki badan arbitrase nasional (BANI) yang cukup lama eksis dalam menyelesaikan sengketa perdagangan dan bisnis baik di lingkup nasional maupun internasional. Pemilihan forum arbitrase internasional sebagai lembaga penyelesaian sengketa tidak dapat dilepaskan dari motif pemilik modal asing untuk mengamankan nilai modalnya (Dewi, 2019:17).

Dalam mewujudkan nasionalisme penyelesaian sengketa penanaman modal asing adalah dengan memberdayakan BANI untuk menggantikan dominasi arbitrase internasional sebagai lembaga penyelesaian sengketa antara investor asing dengan pihak Indonesia (Dewi, 2019:17-18).

Pemberdayaan menurut Kamus Besar Bahasa Indonesia berarti proses, cara, perbuatan memberdayakan. Lebih lanjut memberdayakan berarti membuat berdaya. Pemberdayaan Badan Arbitrase Nasional Indonesia berarti suatu proses atau cara untuk membuat lembaga arbitrase nasional tersebut berdaya utamanya dalam menyelesaikan sengketa penanaman modal asing (Dewi, 2019:18).

Proses beracara di lembaga arbitrase nasional Indonesia dilakukan seperti badan-badan arbitrase lainnya dan BANI bahkan telah melakukan kerjasama dengan badan-badan arbitrase negara lain seperti Jepang, Kanada, Australia, Singapura dan lain-lain. Kualitas arbiter baik arbiter domestik maupun arbitrase asing BANI juga tidak kalah dengan arbiter lembaga arbitrase internasional. Pemberdayaan BANI dalam sengketa penanaman modal asing merupakan langkah penting untuk memajukan dan mengembangkan eksistensi badan arbitrase nasional tersebut dalam menyelesaikan sengketa yang terjadi di wilayah Republik Indonesia (Dewi, 2019:18).

Pasal 1 angka 1 UU No. 30 Tahun 1999 tentang Arbitrase dan Alternatif Penyelesaian Sengketa memberikan definisi arbitrase sebagai cara penyelesaian sengketa perdata di luar peradilan umum yang didasarkan pada perjanjian arbitrase yang dibuat secara tertulis oleh para pihak yang bersengketa. Berdasarkan rumusan pasal tersebut dapat diketahui bahwa penyelesaian melalui arbitrase lahir karena perjanjian tertulis yang dibuat oleh para pihak untuk menyelesaikan sengketa melalui jalur di luar peradilan umum atau melalui arbitrase (Dewi, 2019:33).

Selanjutnya Pasal 1 angka 3 UU No. 30 Tahun 1999 tentang Arbitrase dan Alternatif Penyelesaian Sengketa menyatakan bahwa perjanjian arbi trase adalah suatu kesepakatan berupa klausula arbitrase yang tercantum 
dalam suatu perjanjian tertulis yang dibuat para pihak sebelum timbul seng keta, atau suatu perjanjian arbitrase tersendiri yang dibuat para pihak setelah timbul sengketa. Jadi perjanjian arbitrase merupakan perjanjian tertulis yang memuat klausula mengenai kesepakatan para pihak untuk menyelesaikan sengketa lewat jalur arbitrase. Perjanjian arbritase dapat dijadikan menjadi dua bentuk antara lain adalah Pactum de Compromittendo dan Akta kompromis (Dewi, 2019:33).

Pactum de Compromittendo berarti kesepakatan setuju dengan putusan arbiter. Bentuk klausul diatur dalam Pasal 2 UU No. 30 Tahun 1999 yang berbunyi (Dewi, 2019:34):

"Undang-undang mengatur penyelesaian sengketa atau beda pendapat antara para pihak dalam suatu hubungan hukum tertentu yang telah mengadakan perjanjian arbitrase yang secara tegas menyatakan bahwa semua sengketa atau beda pendapat yang timbul atau yang mungkin timbul dari hubungan hukum tersebut akan diselesaikan dengan cara arbitrase atau melalui alternatif penyelesaian sengketa."

Pasal tersebut mengatur tentang kebolehan para pihak untuk membuat persetujuan dalam menyelesaikan perselisihan yang mungkin timbul kepada arbitrase atau alternatif penyelesaian sengketa. Persetujuan yang dimaksud adalah klausul arbitrase. Pasal 2 UU No. 30 Tahun 1999 tidak mengatur secara tegas mengenai cara pembuatan pactum de compromittendo, namun dalam praktek sering dijumpai dua cara yang dibenarkan yaitu dengan mencantumkan klausul arbitrase dalam perjanjian pokok atau pactum de compromittendo terpisah dengan perjanjian pokok (akta sendiri).

Akta kompromis merupakan perjanjian arbitrase yang dibuat setelah timbul perselisihan antara para pihak atau dengan kata lain dalam perjanjian (perjanjian pokok) tidak diadakan persetujuan arbitrase. Dalam perjanjian pokok para pihak belum mengatur tentang persetujuan mengenai arbitrase dan setelah timbul sengketa para pihak membuat perjanjian baru yang terpisah dari perjanjian pokoknya mengenai kesepakatan untuk menyelesaikan sengketa lewat arbitrase.

Penyelesaian sengketa melalui arbitrase internasional memiliki hambatan sehubungan dengan pelaksanaan dan pengakuan putusannya. Kesulitan tersebut berkaitan dengan harta yang harus dieksekusi di negara yang dikalahkan. Keberhasilan dari penyelesaian sengketa melalui arbitrase internasional ditentukan oleh dapat atau tidaknya putusan yang dihasilkan lembaga tersebut untuk dieksekusi di negara yang dikalahkan (Dewi, 2019:95).

Dalam perjanjian arbitrase, para pihak diberi kebebasan untuk menentukan acara arbitrase yang digunakan dalam pemeriksaan sengketa dengan batasan tidak boleh bertentangan dengan ketentuan yang berlaku. Selain hukum acara arbitrase, para pihak juga perlu menentukan jangka 
waktu pemeriksaan, pilihan hukum dan tempat penyelenggaraan arbitrase. Dalam hal para pihak belum menentukan ketiga hal tersebut, majelis arbitrase akan mengambil alih penentuan untuk para pihak (Dewi, 2019:95).

Klausula tentang penyelesaian sengketa antara penanam modal asing dengan negara diatur dalam Pasal 32 ayat (4) UU Penanaman Modal yang berbunyi sebagai berikut.

"Dalam hal terjadi sengketa di bidang Penanaman Modal antara pemerintah dengan Penanam Modal asing, para pihak akan menyelesaikan sengketa tersebut melalui arbitrase internasional yang harus disepakati oleh para pihak." Lembaga arbitrase yang biasa dipilih seperti ICSID/International Centre for the Settlement of Investment Dispute), ICC International Chamber of Commerce di Paris, SIAC/Singapore International arbitration Centre atau mengikuti rules dari UNCITRAL/United Nation of Comission on International Trade Law (Dewi, 2019:95).

Salah satu kelebihan penyelesaian sengketa melalui arbitrase dibanding jalur litigasi adalah prosesnya yang dapat berlangsung lebih cepat. Untuk mengakomodir hal tersebut, proses pemeriksaan dalam sidang arbitrase dibuat lebih sederhana dalam jangka waktu yang ditentukan sehingga bisa dihasilkan putusan dalam waktu yang relatif singkat. Namun aturan mengenai pembatasan waktu tidak ditemukan baik dalam peraturan BANI, UNCITRAL maupun ICSID.

Satu-satunya ketentuan yang mengatur tentang pembatasan waktu pemeriksaan adalah Rv yaitu dalam Pasal 620 jo. Pasal 624 dan Pasal 628. Pasal $620 \mathrm{Rv}$ menentukan bahwa para pihak dalam perjanjian arbitrase harus menentukan batas jangka waktu penyelesaian sengketa. Apabila para pihak tidak mencantumkan mengenai hal tersebut maka kuasa yang diberikan oleh Undang-Undang kepada Mahkamah Arbitrase hanya berlaku 6 bulan. Dari ketentuan tersebut dapat diketahui bahwa penentuan jangka waktu pemeriksaan arbitrase didasarkan pada kesepakatan para pihak dan dalam hal para pihak belum menyepakatinya maka majelis arbiter diberikan waktu oleh Undang-Undang dalam jangka waktu 6 bulan (Dewi, 2019:112).

Arbiter yang gagal menyelesaikan tugasnya dalam jan waktu yang ditentukan dibebankan tanggung jawab untuk mengganti kerugian kepada para pihak. Namun jika terbukti kelalaian dalam menyelesaikan tugas tersebut terjadi karena alasan yang dapat diterima maka kewajiban ganti rugi dapat ditolak (Dewi, 2019:112).

\section{DAFTAR PUSTAKA}

Atika Dewi, Ayu. (2019). Penyelesaian Sengketa Penanaman Modal asing melalui Arbitase, Yogyakarta. Suluh Media tahun. 
Ariesta, Indah. (2014). Peran Arbitrase Syariah Nasional (Analisis Putusan no. 15/ tahun 2007 Basyarnas, Kajak), Skripsi, Bengkulu 2014.

Sudiyana, Pemberdayaan Peran Arbitrase Lembaga dalam Penyelesaian sengketa Bisnis di Indonesia

Wahid, Abdul. (2005). Mekanisme penyelesaian sengketa bisnis melalui arbitrase; tesis: program magister ilmu hukum Universitas Diponegoro Semarang.

Zaidah, Yusna. (2016). Lembaga arbitrase Islam di Indonesia; IAIN Antasari fakultas Syariah.

Novita Elparasi, Jerina. Perluasan keikutsertaan pengadilan nasional terhadap proses arbitrase di Indonesia: harmonisasi undang-undang nomor 30 tahun 1999 tentang arbitrase dan penyelesaian sengketa alternatif dengan Uncitral Model law 1985/2006; Perluasan Keikutsertaan Pengadilan Nasional terhadap Proses Arbitrase di Indonesia: Harmonisasi Undang-Undang Nomor 30 tahun 1999 tentang Arbitrase dan Penyelesaian Sengketa Alternatif dengan UNCITRAL Model Law 1985/2006 | Padjadjaran Law Review (unpad.ac.id)

Farah dan Sufi; (2020). Dasar kewenangan lembaga arbitrase dalam menyelesaikan suatu sengketa (Studi kasus pada perkara nomor 229/Pdt.G/2018/PN.Jkt.Sel).

Lusianah, (2008). Peranan badan arbitrase Syariah nasional (BASYARNAS) dalam penyelesaian sengketa ekonomi syariah menurut undangundang nomor 03 tahun 2006 tentang Peradilan Agama, Universitas Tarumanegara.

Multazam, Muhammad tanzil; (2006). Arbitrase sebagai salah satu alternatif penyelesaian sengketa di Indonesia; Sidoarjo, Universitas Muhammadiyah.

Wagianto, (2020). Penegakan Hukum melalui Arbitarse Syariah; Jakarta: Arjasa Pratama.

Hayatuddin, Amrullah. (2013). peran peradilan agama dan badan arbitrase syariah dalam penyelesaian sengketa ekonomi syariah; jurnal lembaga keuangan dan perbankan syariah.

Sulfiayu, dan Hasriadi; Kajian kritis tentang relevansi arbitrase menurut undang-undang nomor 30 tahun 1999 dalam penyelesaian sengketa ekonomi syariah, IAIN Bone Indonesia

Widyorini, Tri Retno. Penyelesaian sengketa dengan cara arbitrase. PENYELESAIAN SENGKETA DENGAN CARA ARBITRASE | Widyorini | Jurnal Ilmiah Hukum Dan Dinamika Masyarakat (untagsmg.ac.id)

Rijanto, Raden. (2014) Aspek Hukum dalam Ekonomi. Sukabumi: Al Fath Zumar. 
Atika Dewi, Ayu. (2019) Penyelesaian Sengketa Penanaman Modal Asing Melalui Arbitrase. Yogyakarta: Suluh Media, Ruko Jambusari 7A, 55283. 